\title{
INSKRIPSIES UIT OUD-TESTAMENTIESE TYD
}

\author{
Opgedra aan prof. dr. J. H. Kroeze \\ by sy sewentigste verjaarsdag.
}

In Die Vaderland van 10 April 1967 het daar 'n klein persberiggie verskyn wat meld dat daar by die opgrawinge te Deir cAlla in Transjordanië onder leiding van dr. H. J. Franken 'n onbekende skrif ontdek is, „wat dui op 'n onafhanklike groep wat gedurende die Bybelse tyd in Transjordanie gewoon het". Inderdaad is daar deur dieselfde Nederlandse ekspedisie onder die bekwame leiding van dr. Franken in 1964 al kleitablette met 'n onbekende skrif (vermoedelik dieselfde as wat die persberiggie bedoel) gevind. In 'n kort nota enkele dae na die vonds het dr. Franken by foto-afdrukke van die tablette gemeld dat sommige letters van die waarskynlik alfabetiese skrif ooreenkoms vertoon met die Fenisiese Byblosskrif van Ahiram, maar dat daar waarskynlik ook 'n Suid-Semitiese element in die skrif aanwesig is. Die tablette word gedateer in ongeveer die einde van die dertiende, begin van die twaalfde eeu v.C.')

Hoe groot die betekenis van hierdie ontdekking ook is, en hoeveel lig dit miskien ook kan werp op die geskiedenis van o.a. die drie Israelitiese stamme wat in Transjordanie gaan woon het, kan daar op hierdie stadium niks verder daaroor gesê word voordat daar meer bekend is oor die hele resultaat van die opgrawing te Deir cAlla, en voordat die nuwe skrif ontsyfer en die inhoud van die geskrifte bestudeer is nie.

Tog het hierdie ontdekking die lig skerp laat val op, en is daar ook navraag na, wat reeds aan inskripsies uit Palestynse bodem na vore gekom het.

Dit is 'n bekende feit dat daar baie min inskripsies uit Palestynse bodem aan die lig gekom het tot voor die Tweede Wêreldoorlog. Hoofsaaklik was toe bekend die Geser-kalender, die Samaria-ostraka, die Siloa-inskripsie, die Silwān-grafskrif en die Lagis-briewe, en verwant hieraan uit Moabitiese gebied, die Mesa-steen. Die inhoud van hierdie inskripsies is al dikwels voorheen beskryf en bestudeer.

$\mathrm{Na}$ die Tweede Wêreldoorlog het daar deur opgrawingsaktiwiteite 'n verrassende aantal nuwe inskripsies aan die lig gekom. Hierdie nuwe inskripsies stel die navorsers in staat om baie lakunes in verband met die Israelitiese geskiedenis, 
paleografie ens. op te vul. ' $n$ Hele aantal inskripsies is van kleiner omvang, soms enkele letters, waarvan die betekenis nie maklik vasgestel kan word nie; so bv. die bekende inskripsies op kruikhandvatsels. 'n Aantal, met name dié op seëls, bevat hoofsaaklik name. Hoewel hierdie inskripsies allermins sonder betekenis is, sal ons in hierdie artikel daarby verbygaan, en slegs konsentreer op inskripsies van groter omvang met samehangende inhoud.

By die bespreking van die vroeër reeds bekende inskripsies sal geen transskripsie van die oorspronklike gegee word nie, en sal ook nie in detail op teks- en vertalingsprobleme gewys word nie.

\section{Geser-kalender}

Die sg. Geser-kalender dateer ongeveer uit die tweede helfte van die tiende eeu v.C. ${ }^{2}$ ) en is in 1908 gevind by die opgrawings te Geser. Dit bevat 'n inskripsie wat deur sommige beskou word as die skryfproduk van 'n skoolleerling wat die tabletjie as 'n soort lei gebruik het; daar is tekens dat 'n vroeëre inskripsie op die tablet uitgevee is en hierdie daaroorheen geskryf is..3) Die teks gee in kort sinnetjies die tydsduur aan van die vernaamste landbouwerksaamhede van dié tyd. Daarom word dit ook soms genoem die Boerekalender van Geser. Oorgesit in Afrikaans lui die inskripsie soos volg:

1. Twee maande ${ }^{4}$ ) (is) insameling; twee maande

2. (is) saai(tyd); twee maande is na-gras;

3. een maand (is) vlas sny;

4. een maand (is) koring oes;

5. een maand (is) oes en afmeet;

6. twee maande (is) snoei (d.i. druiwe snoei);

7. een maand is (oes van) somervrugte.

Hierdie is dus nie eintlik ' $n$ kalender of almanak in die regte sin van die woord nie, maar dit word deur sommige gesien as die skoolwerk van 'n skoolseun wat gewoond was om sy ouers op die land te help. $\left.{ }^{6}\right)$ Ander egter meen dat die kalender deur die voorman van dagloners gebruik is om kontrole oor die arbeid uit te oefen.7)

\section{Samaria-ostraka}

Tydens die opgrawing van die paleis by die ou Samaria het daar 63 Hebreeusc ostraka (beskrewe potskerwe) te voor- 
skyn gekom. Verskillende gegewens wys op 'n datering in die negende tot agtste eeu v.C. ${ }^{8}$ ) Die geleerdes stem nie saam oor die presiese datering nie, ${ }^{9}$ ) maar miskien is 'n datering tydens die regering van koning Jerobeam $\mathrm{II}^{10}$ ) of koning Menahem van Israel"1) die beste.

Die aard van die inhoud van hierdie ostraka word hier deur die oorsetting van slegs drie ostraka geillustreer.

Nr. 5, 6 en 7 is duplikate van $\left.\mathrm{nr},{ }^{4},{ }^{12}\right)$ en lui soos volg:

1. In die negende jaar,

2. van $q s \underline{h}$ aan $g d$

3. $j w$ 'n kruik

4. ou wyn.

Nr. 19:

1. In die tiende jaar,

2. van jṣt 'n kruik

3. kosmetiese olie

4. aan ' $h n^{c} m$.

Nr. 54:

1. In die tiende jaar, wyn van

$2 / 3$. die wymberg (wingerd?) van $t l$; 'n kruik kosmetiese olie.

Die eie-name, wat hier kursief weergegee is, is na die preposisie "aan" dié van persone (sien gdjw in nr. 4 reël 2-3). ${ }^{13}$ ) Anders is dit plekname. ${ }^{14}$ )

Die waarskynlikste verklaring vir die betekenis van hierdie ostraka is dat dit 'n notering was van versende wyn en/of olie, wat die besending na die koninklike pakhuise te Samaria vergesel het. Die ostraka is geen duursame, permanente verslae nie, maar slegs tydelike notas, en bevat slegs die noodsaaklikste aantekeninge. Daarom kan ook geen groter betekenis daaraan gegee word nie. ${ }^{15}$ )

\section{Siloa-inskripsie}

In 1880 is daar in Jerusalem in die ondergrondse tonnel wat die „Jonkvrou-bron" met die sg. Siloa-bron verbind, 'n inskripsie ontdek ongeveer agt treë van die mond van die tonnel af. Die inskripsie beslaan ses reëls, maar daar is 'n veel groter gedeelte glad gemaak op die rots waar dit inge- 
graveer is, en die gedagte bestaan dat die orige spasie bedoel was vir een of ander afbeelding, wat egter nooit verskyn het nie. Die tonnel is gegrawe in die tyd van koning Hiskia ${ }^{16}$ ) en moes ongeveer in die jaar 700 v.C. ontstaan het. Hierdie is trouens die enigste monumentale Hebreeuse steen-inskripsie wat tot dusver gevind is, en dit word tans bewaar in ' $n$ museum in Istambul. Die inskripsie beskryf die werksaamhede aan die bou van die tonnel soos volg:

1. ... ${ }^{17}$ ) die deurboring. Dit is die geskiedenis van die deurboring: terwyl [die werkers geswaai het]

2. die pik, die een teen die ander, en terwyl daar nog drie el om te deurboor [oor was is geho]or die stem van die een roepen-

3. de die ander. Want daar was 'n spleet in die rots, van regs en van [link]s. ${ }^{18}$ ) En op die dag van die

4. deurboring het die werkers die een die ander tegemoet gekap, en gevloei het

5. die water van die uitgang na die vywer twaalfhonderd el ver, en honderd el was die hoogte van die rots bo die kop van die werkers.

Die beplanning vooraf en die uitvoering van die werk aan hierdie ondergrondse watertonnel, met 'n lengte van 1749 vt., 'n hoogte van ongeveer 6 vt. en 'n val oor sy lengte van ongeveer 7 vt., ,moet gereken word tot die knapste ,ingenieurswerke" van die volk Israel". ${ }^{9}$ )

\section{Silwān-grafskrif}

In 1899 is by die dorpie Silwān naby Jerusalem bo die ingang van ' $n$ graf ' $n$ inskripsie gevind. Dit is die eerste Hebreeuse grafskrif wat bekend geword het, en dit vertoon sterk stilistiese ooreenkoms met die Fenisiese grafskrifte.

Toe hierdie grafskrif ontdek is, het die ontdekker dit uitgesaag en na Londen gestuur. Dit was egter so beskadig dat niemand dit kon ontsyfer nie. In 1953 egter het prof. N. Avigad van Jerusalem met 'n baie merkwaardige metode die verrassende resultaat behaal dat hy byna die hele teks kon ontsyfer. Hy het $\mathrm{nl}$. fotos van die teks vergelyk met 'n papier-,,afdruk" daarvan, ${ }^{20}$ ) en die volgende teks openbaar gemaak:

1. Dit is [die graf van ...] jhw, wat oor die huis is. Hier is gce: silwer en goud nie 
2. maar [sy gebeente] en die gebeente van sy slavin-vrou met hom. Vervloek is die man wat

3. dit oopmaak.

Hierdie grafskrif word op grond van die paleografiese getuienis gedateer in ongeveer die jaar 700 v.C., en die versoeking is groot om op grond van een en ander dit te verbind aan "Sebna, wat oor die huis is" (Jes. 22 : 15 e.v.). ${ }^{21}$ ) Die beskadiging van die naam in die inskripsie maak hierdie identifikasie egter onseker.

\section{Grafskrif van Hirbet Leji}

Pas in 1963 is die inskripsies in 'n graf by Hirbet Lejj, ongeveer vyf myl oos van Lagis, bekend gemaak. Die graf is ontdek tydens werksaamhede aan die aanleg van 'n pad. Die graf bestaan uit ' $n$ voorkamer en twee grafkamers. Behalwe die inskripsies is daar ook ruwe tekeninge op die rots gevind van drie mensefigure - een met ' $n$ lier, een in gebedshouding en een met ' $n$ merkwaardige hooftooisel - en van twee seilskepe. ${ }^{22}$ )

Van die sewe verskillende inskripsies wat hier aangetref is, word slegs die drie groteres hier weergegee. Die ontdekker vertel met watter groot probleme hy te kampe gehad het om die letters van die betrokke inskripsies te onderskei van ander merke aan die rots. ${ }^{23}$ )

Die inskripsies word soos volg gelees:

i) jhwh 'lhj kl h'rs $h$ ri jhd lw l'thj jršlm

Jahwe is die God van die hele aarde; die

berge van Juda behoort aan Hom, aan die God van Jerusalem.

ii) hmwrih 'th hnnt nwh jh jhwh

Die Moria het u begunstig, die woonplek van Jah, Jahwe.

iii) $h w \check{s}^{c}[j] h w h$

Verlos, Jahwe!

Die eerste inskripsie bevat etlike merkwaardighede. Die uitdrukking "God van die hele aarde" kom in die O.T. slegs een keer voor, nl. in Jes. 54:5: „... Hy sal die God van die hele aarde genoem word". Die gedagte dat God oor die hele 
aarde regeer kom egter natuurlik dikwels voor; ook uitdruk. kings soos "die God van hemel en aarde", „Here van die hele aarde", „koning oor die hele aarde", ens.; en ook die uitdrukking "die hele aarde is Myne".

"Berge van Juda" word ook slegs eenkeer in die O.T. gebruik soos hier, nl. in 2 Kron. 21 : 11: „Hy het ook die hoogtes van die berge van Juda gemaak". Anders word altyd die enkelvoud, ,berg van Juda”, gebruik.

Die uitdrukking "die God van Jerusalem" kom in die O.T. slegs voor in 2 Kron. 32 : 19: „En hulle het oor die God van Jerusalem gespreek soos oor die gode van die volke van die aarde", waar dit gesê word in verband met die Assiriërs wat onder Sanherib Jerusalem beleër het. In 'n pragtige rede van Vriezen ${ }^{24}$ ) wys hy o.m. daarop dat hoewel dit dikwels in die O.T. en met name in die Psalms voorkom dat Jerusalem Godstad of stad van die Here genoem word, dit met uitsondering van die teks hierbo genoem uit (die láát ontstane) 2 Kron., nooit gebeur dat van die Here gespreek word as die God van Jerusalem nie.25) Terwyl Vriezen in 'n voetnoot daarop wys dat die woorde uitdruklik in die mond van die heidense Assiriërs gelê word, trek Naveh verder die aandag daarop dat hierdie uitdrukking in 2 Kron. 32: 19 volg op ,die volk van Jerusalem" (vs. 18) in vergelyking met "die gode van die volke van die ander lande" (vs. 11).26)

Dit maak hierdie uitdrukking in ons inskripsie des te meer merkwaardig.

Baie aantreklik is die moontlike verklaring wat Naveh vir die ontstaan van die grafinskripsies bied. Die eerste inskripsie sou uitbring dat die een wat die geskryf het 'n bewoner was van die gebergte van Juda, dat hy na vore bring dat die "berge van Juda" ook aan God behoort, met daaraan verbonde 'n bewustheid van die uitverkiesing van die volk Israel. Die tweede sou die gedagte ontwikkel dat Jerusalem (Moria) verlos is, en die derde sou daarmee samehangend die bede uitspreek dat die berge van Juda en hulle bewoners ook verlos word.

Hierdie gegewens maak die teorie moontlik dat die inskripsies geskryf kon gewees het in 'n tyd toe Juda in gevaar van besetting deur 'n vyand verkeer het, en toe Jerusalem uiteindelik verlos is. Die skrywer(s) van die inskripsies kon onder sulke omstandighede dan 'n toevlug gevind het in die familie-graf, of hulle kon 'n familie-lid wat deur die vyand 
gedood is, kom begrawe het.

Temporeel skyn die moontlikste situering dan te wees tydens die inval van Sanherib, hoewel dit ook tydens die inval onder Nebukadnesar sou kon geplaas word. ${ }^{27}$ )

\section{Lagis-briewe}

Die groep ostraka wat bekend staan as die Lagis-briewe is tydens die opgrawings te Lagis ( tans Tell ed-Duweir) gevind. Agtien ostraka is in 1935 gevind by die hoofpoort van die stad, waar daar origens duidelike tekens was dat ' $n$ brand die oorsaak was van die verwoesting van die stad. Twee volgende ostraka is in 1938 gevind naby die paleis, terwyl nog een gevind is aan die suid-westelike helling van die stad. ${ }^{28}$ )

Die eerste agtien ostraka is volledig beskrywe en ook vertaal en bespreek deur $H$. Torczyner in die eerste opgrawingsberig van Lagis. ${ }^{29}$ ) Behalwe 'n groot aantal verspreide artikels, is ' $n$ volledige, meer besonne vertaling van al een-entwintig ostraka gegee in 'n volledige bespreking van die opgrawingsresultate in verband met die yster-tydperk by Lagis. ${ }^{30}$ )

Die inhoud van hierdie ostraka is van velerlei aard, en dit maak dit bykans onmoontlik om die ostraka as 'n groep te verklaar. Paleografies en ook op grond van stratigrafiese getuienis word die ostraka gedateer in die laaste paar jaar voor die ondergang van die ryk van Juda; die verwoesting van Lagis soos deur die brandlaag aangedui, word daarom toegeskryf aan die optogte van Nebukadnesar in die jare 597 en 586 v.C. ${ }^{31}$ ) Sommige geleerdes wou nog verder gaan en die ontstaan van die briewe koppel aan 'n bepaalde historiese gebeurtenis, soos bv. die dood van die profeet Uria (Jer. $26: 20-23$ ), ${ }^{32}$ ) of die stryd tussen die pro-Babiloniese en pro-Egiptiese partye in Juda ${ }^{33}$ ) Sulke verklarings bly egter geforseerd en het baie besware daarteen.

Wat die saak verder bemoeilik, is dat slegs 'n paar van hierdie ostraka goed leesbaar is. Op vyf daarvan kan behalwe enkele letters so goed as niks gelees word nie. Op ' $n$ verdere aantal kan maar enkele woorde en sinnetjies met sekerheid gelees word, terwyl die verband geheel en al nie duidelik is nie. 'n Paar egter is vry goed leesbaar, en word hier soos volg weergegee: ${ }^{34}$ )

\section{Nr. 2. Aan $J \bar{a}^{\prime} \bar{o} \check{s}$}

1. Aan my heer $j^{\prime} w s$. Mag Jahwe laat hoor

2. aan my heer berigte van vrede 
3. nog vandag. Wie is $u$ kneg,

4. ' $n$ hond, dat my heer gedagtig was aan

5. sy kneg! Mag Jahwe begunstig (?) ...

6. ......35)

Nr. 3. Hošicjahū aan Ja'oš

1. U dienaar $h w s^{c} j h w$ het gestuur om te

2. berig aan my heer $j^{\prime} w s ̌$. Mag Jahwe laat hoor

3. aan my heer berigte van vrede.

4. ... [geopen]

5. ... [die oë van] u dienaar vir die brief wat

6. my heer gister gestuur het, want die hart

7. van u dienaar is bedroef (?) ... sedert u [die brief?] gestuur het aan $\mathrm{u}$ dienaar.

8. En wanneer my heer sê: „Jy weet nie

9. om 'n brief te lees nie", sowaar Jahwe leef, niemand het probeer

10. om ooit vir my 'n brief te lees nie. En ook

11. elke brief wat na my toe gekom het...

12. het ek gelees...

13...$\left.{ }^{36}\right)$ En aan u dienaar is bekend gemaak

14. aldus: die leërowerste het afgegaan

15. nl. knjhw bn 'lntn, om te gaan

16. na Egipte en vir

17. hwdjhw bn 'hjhw en

18. sy manne het hy gestuur om te neem...

19. En 'n brief van $t b j h w$, die dienaar van die koning wat gekom het

20. na $\operatorname{slm} b n j d^{c}$ deur die profeet, seggende:

21. „Pasop!” - dit het u dienaar deurgestuur na my heer.

Nr. 4. Offisiersverslag

1. Mag Jahwe aan my heer laat hoor selfs vandag

2. goeie berigte. En nou, volgens alles wat my heer beveel het,

3. so het $u$ dienaar gedoen. Ek het op die deur ${ }^{37}$ ) geskryf volgens alles

4. wat... aan my beveel het. En wanneer my heer geskryf het

5. aangaande bjt $\left.h r p d{ }^{38}\right)$ daar is geen mens nie.

6. En wat betref $s m k j h w, \breve{s} m^{c} j h w$ het hom geneem en 
7. hom na die stad toe opgebring. En wat $\mathbf{u}$ dienaar betref, ek het nie

8. gestuur daarheen ${ }^{39}$ )...

9. maar wanneer dit more word [sal ek stuur?].

10. En mag (my heer?) weet dat ons op die vuursinjale van Lagis

11. let, volgens al die tekens wat my heer vasgestel het,

12. want ons sien nie (die tekens van) Ase-

13. ka nie.

Nr. 5. (Sonder aanhef)

1. Mag Jahwe my heer laat hoor

2. berigte van vrede en van geluk, selfs

3. vandag, selfs vandag. Wie is $u$ dienaar,

4. 'n hond, [dat $u$ gestuur het] aan [u] dienaar

5. die brief ...

6. U dienaar het die briewe teruggestuur

7. na my heer. Mag Jahwe u laat sien

8. .......

9. ... sal vir u dienaar

10. tbjhw die saad $l m l k$ [bring]? ?99a)

Nr. 6. Aan Jā'ōs

1. Aan my heer j'wš. Mag Jahwe laat sien

2. aan my heer in hierdie tyd vrede! Wie

3. is u dienaar, 'n hond, dat my heer gestuur het [die brief?]

4. van die koning en die briewe van die vorste, seggen-

5. de: Lees tog. En kyk, die woorde van die [ . .

6. is nie goed om te verslap $u$ hande ${ }^{40}$ )

7. .......4

8. ... my heer, sal u nie

9. soos volg skryf nie: [Waarom] doen julle

10. so $\ldots 4^{42}$ )

Uit die briewe wat hier weergegee is, en ook uit die fragmente van sommige ander blyk dit dat ten minste 'n gedeelte van hierdie ostraka as briewe gestuur moes gewees het aan, soos dit voorkom, die bevelvoerende offisier, Jā'ōš, in Lagis. Uit nr. 4 (offisiersverslag, sien bo) blyk dan ook dat uit Lagis en Aseka vuursinjale gegee was, miskien uit die stadstorings, met 'n vooraf afgesproke betekenis, wat deur die skrywer van ons verslag uit 'n derde vesting of militêre 
pos opgevang was. Die skrywer gee hiermee aan sy bevelvoerder kennis dat die sinjale uit Aseka nie meer sigbaar is nie, en dat hulle nou let op die sinjale uit Lagis.

Wanneer hierdie reëls vergelyk word met Jer. 34 : 7: „.... terwyl die leër van die koning van Babel oorlog voer teen Jerusalem en teen al die stede van Juda wat oorgebly het, teen Lagis en teen Aseka: want hulle het as versterkte stede oorgebly onder die stede van Juda", kan dit beteken dat Aseka ten tye van die skrywe van ons verslag alreeds deur die Babiloniërs ingeneem was. Hoewel daar ook ander redes mag wees waarom die verslag meld dat Aseka nie meer sig. baar is nie, ${ }^{43}$ ) is hierdie tog 'n baie aanloklike verklaring. Dit blyk hieruit ook dat ten minste 'n deel van die briewe geskryf moes gewees het in die hitte van die stryd teen die Babiloniërs buite Jerusalem, toe daar van vuursinjale gebruik gemaak was om vooraf afgesproke boodskappe oor te sein.4)

'n Hele paar van die briewe bevat 'n verslag van uitgevoerde opdragte, of van sekere gebeurtenisse, 'n aanvraag om voedsel en saad, of 'n versoek om opdrag te ontvang vir die volgende dag. Van briewe word daar egter die heel meeste melding gemaak, hoewel meestal nie uitgemaak kan word wat dit presies beteken nie. In nr. 3 verweer die skrywer $\left(h \zeta^{c} j h w\right)$ hom teen 'n aanklag met betrekking tot die lees van briewe, en hy meld van 'n brief van tbjhw, die dienaar van die koning, aan $\zeta l m$, wat deur die profeet oorgebring is. In nr. 5 meld die skrywer dat hy sekere briewe teruggestuur het. In nr. 6 gee die skrywer sy oordeel oor die briewe van die koning en die vorste, wat sy heer aan hom gestuur het om te lees. En in nr. 18 bv. meld die skrywer dat hy 'n brief van sy heer sal stuur (d.i. verder deurstuur vir ander om te lees?).

Daar bly baie vraagtekens oor in verband met die Lagisbriewe. Die direkte historiese gegewens uit die briewe is relatief gering, en die betekenis daarvan lê meer op taalkundige, paleografiese en tekskritiese terrein. Tog word daardeur die lewende mense van die tyd kort voor die val van Jerusalem aangrypend naby gebring. En dit maak die briewe, ook histories, van onskatbare waarde.

\section{Klag van 'n oester}

Tydens die opgrawing van 'n fort naby Jamnia, of JabneJam, ongeveer halfpad tussen Jaffa en Asdod, is daar in 1960 'n hele paar inskripsies gevind, waarvan die belangrikste hier- 
die ostrakon onder bespreking. ${ }^{45}$ ) $\mathrm{Na}$ die naam wat op die ostraka voorkom, word die rünes tans genoem Meșad Hašabjahu (d.i. Fort van H.). ${ }^{46}$ ) Dit word taamlik algemeen aanvaar dat die fort en ook die inskripsie dateer uit die tweede helfte van die sewende eeu v.C., soms nader bepaal tot ongeveer 625 v.C.47) In elk geval val die datering tydens die regering van Josia, koning van Juda. Nou is dit merkwaardig dat daar onder hierdie vrome koning ' $n$ fort bestaan het in hierdie gebied wat ver buite die eintlike grense van die ryk van Juda val. Koning Josia het egter sy hervorminge op godsdienstige gebied, ook volgens Bybelse getuienis, tot ver binne die gebied van die ou ryk van Israel (die Tienstammeryk) deurgevoer ( 2 Kon. $23: 15 ; 2$ Kron. $34: 6$ ), en die gedagte het ontstaan dat Josia daarna gestreef het om sy ryk uit te brei tot die grootte van sy groot voorganger, Dawid. Hiermee word die fort by Meșad Hašabjahu dan in verband gebring; dit lê op 'n strategiese posisie wat juis gunstig was vir militêre bewaking van die groot weg langs die see.

Die skrif op hierdie inskripsie is baie netjies, en is sonder twyfel dié van iemand wat gewoond was om te skryf. Vergeleke met die soms hortende taal van die inskripsie kan dit moeilik aanvaar word dat die skrywer in sy eie woorde die klag van die inskripsie opgeskryf het. Dit skyn eerder asof die klaer 'n professionele skrywer gekry het om sy klag op skrif te stel, en dat die skrywer die direkte woorde van die klaer neergeskryf het, behalwe miskien die aanhef. ${ }^{48}$ )

Die teks lui soos volg:

1. $j \zeta m^{c}$ 'dnj hisr

2. 't $d b r{ }^{c} b d h{ }^{c} b d k$

3. $q s \mathrm{~s} h \mathrm{hih}$ cbdk bh

4. $[s r$ 's]m wjqst cbdk

5. $w j k l$ w'sm kjmm ${ }^{49}$ ) lpnj šb

6. $t k^{\prime} s ̌ r k l$ [c]bdk' $t$ qsr[h] $w^{\prime}$

7. sm kjmm wjb' hwšcjhwol) bn šb

8. $j$ wjqh 't bgd cbdk k'sr klt

9. 't qsrj $z h$ jmm lqh 't bgd cbdk

10. wkl ' $h j$ jc $n w$ lj hqșm 't $j$ bhm

11. [hšmš wkl] 'hj jcnw lj 'mn [n]qtj m'

12. [šm hšb n' 't] bgdj w'ml' lśr lhš

13. [b 't bgd cbdk wjt]n $c l w$ rh

14. [mm ... c]bdk wl' tdhmn... 
Vertaling:

1. Laat my heer die goewerneur hoor

2. die woord van sy dienaar. U dienaar,

3. aan die oes was $u$ dienaar in Ha-

4. sar 'Asam. ${ }^{51}$ ) En $u$ dienaar het ge-oes

5. en klaargemaak, ${ }^{52}$ ) en versamel soos gewoonlik ${ }^{53}$ ) voor die Sab-

6. bat. $^{54}$ ) Toe u dienaar sy oes klaargemaak het en versa-

7. mel het soos gewoonlik, ${ }^{53}$ ) daar kom Hōšicjahu ben Soba-

8. $\mathrm{j}$ en hy vat die bo-kleed van $\mathrm{u}$ dienaar. Toe ek klaargemaak het

9. (met) my oes daardie (bepaalde) dae, het hy die bokleed van u dienaar weggevat.

10. Maar al my broers ${ }^{55}$ ) sal vir my getuig, die wat geoes het saam met my in die hitte

11. [van die son. Al] my broers sal vir my getuig. Waarlik, ek is [v]ry van sku-

12. [ld. ${ }^{56}$ ) Gee tog terug] my bo-kleed..$^{57}$ ) Ek smeek ${ }^{58}$ ) die goewerneur om terug te

13. [gee die bo-kleed van $u$ dienaar en te bewy]s aan hom gu-

14. [ns ... u die]naar en moet my nie afwys nie..99)

Oor die besonderhede van dic interpretasie van hierdie brief is daar wel verskil. Algemeen word egter aanvaar dat dit hier gaan om die klag van iemand wat om sekere redes 'n bepaalde stuk oeswerk moes afhandel, dat hy meen dat hy dit wel voltooi het, maar dat die opsigter anders geoordeel het en daarom sy bo-kleed afgeneem het; die klaer versoek nou teruggawe van sy kleed. Die wyse van straf dui daarop dat hierdie arbeider nie 'n huurling was nie, omdat die tekort op sy arbeid dan verhaal kon word op sy loon. Daarom word gemeen dat hy of dwangarbeid moes verrig in diens van die koning, of as landbouer in vaste diens van die koning gestaan het, en daarom 'n vaste prestasie moes lewer (vgl. 2 Kron. 26 : 10). ${ }^{60}$ ) Dit blyk ook dat hy saam met ander arbeiders op die land gewerk het, na wie hy verwys in sy pleit.

Die bo-kleed was veral vir die armer man 'n baie kosbare besitting. Behalwe as bo-kleed, is dit snags ook gebruik as deken om die eienaar te beskerm teen die koue. ${ }^{61}$ ) Dit was dus 'n swaar straf om van die bo-kleed beroof te wees; en dít was waarskynlik ook die bedoeling van die amptenaar 
teen wie die klag nou gaan. Maar ewe-eens was dit vir die klaer in sy posisie aanleiding om die petisie in te dien, waarskynlik met die wete dat die Mosaïese wetgewing sy klag ondersteun (vgl. Eks. 22 : 26-27).

\section{Tel Arad-ostraka}

Tydens die derde seisoen van opgrawings te Tel Arad is daar 'n aantal ostraka gevind in die argiewe van die laaste fort, wat gedateer word in die tyd voor die Judese ballingskap. ${ }^{62}$ ) Die skrif van hierdie ostraka stem baie ooreen met dié van die Lagis-briewe, hoewel hulle blykbaar deur verskillende skrywers geskryf moes gewees het. Op grond van allerlei gegewens bestaan die mening dat hierdie ostraka geskryf moes gewees het kort voor die verwoesting van hierdie Judese fort, in die jare rondom 598 of 586 v.C.63)

Byna al die ostraka, so word ons meegedeel, is gerig aan 'n sekere Eljašib, en dit bevat hoofsaaklik instruksies om sekere persone te voorsien van voorrade, veral van wyn, brood en olie. ${ }^{64}$ )

Twee ostraka is tot dusver as voorbeelde van wat hier gevind is, meegedeel, en lees soos volg:

i) 1. 'l 'ljšb $w$

2. 't ntn lktjm

3. ijn $b[\mathrm{tm}] 3($ ?). $w$

4. $k t b \quad s m ~ h i m$

5. $w m^{c} w d$ hqmh

6. $h r^{\prime} \operatorname{sh} t$

7. $r[b k]$ (efa) 1 qmh

8. lcst $\operatorname{lhm} l$

9. $h m \cdot m j i n$

10. h'gnt th

Vertaling:

1. Aan Eljašib. En

2. nou: gee aan die Kittim

3. drie bat wyn, en

4. skryf die naam van die dag.

5. En van die res van die eerste

6. meel laat

7. daar gemeng word 1 efa meel

8. om vir hulle te maak b- 
9. rood. Van die wyn

10. van die kelders - gee!

ii) 1 . ' $l$ ' $d n j$ ' $l j$

2. $\check{s} b$. jhwh $j \check{s}$

3. 'l lsslmk. w't

4. tn lšmrjhw

5. [?] wlqrsj

6. $\operatorname{ttn}$ (?). wld

7. $b r$ 'srs

8. winj šlm

9. bit jhwh

10. $h^{\prime} j \xi b$

Vertaling:

1. Aan my heer Elja-

2. šib. Mag Jahwe (laat) vr-

3. a na u vrede. En nou:

4. gee aan Semarjahu

5. ... En aan die Qeroșiet

6. gee ... En aangaande die sa-

7. ak wat u my be-

8. vel gegee het - vrede!

9. In die huis van Jahwe

10. hou hy verblyf.

Die feit dat ook in die ander briewe, volgens die mededeling, daar ' $n$ hoflike begroeting ontbreek, en dat die ostraka kort, presiese opdragte bevat, meestal oor die voorsiening van voorrade, gee aanleiding tot die gedagte dat hulle geskryf is deur 'n hooggeplaaste offisier. Klaarblyklik is die ostraka na Arad toe gebring deur die mense wat die voorrade in ontvangs moes neem, en die ostraka het dan terselfdertyd gedien as magtiging vir die ontvangs van die voorrade. Dit blyk veral uit die tweede ostrakon hierbo. Die twee genoemde manne is waarskynlik op 'n sending uitgestuur, en het by wyse van die ostrakon magtiging gehad om voorrade vir die reis in ontvangs te neem.

Op die agterkant van 'n ander ostrakon wat 'n soortgelyke opdrag bevat, is ' $n$ aantekening in 'n ander handskrif in die sin dat die opdrag uitgevoer is op 'n sekere datum; die astrakon is dus bewaar as 'n soort kwitansie. ${ }^{64 a}$ )

In die eerste brief hierbo ontstaan die vraag: wie is die 
Kittim? In die O.T. word met Kittim meestal aangedui Cypriote, inwoners van die Argipel, of Romeine.65) Dit is verder bekend dat daar in hierdie tyd Griekse huursoldate in die Babiloniese leër geveg het. ${ }^{66}$ ) Die groot hoeveelheid potskerwe van Griekse herkoms by Meșad Hašabjahu ${ }^{67}$ ) maak dit baie waarskynlik dat daar ook in die Judese leër Griekse huursoldate of handelaarsgarnisoene gedien het, miskien as garnisoen-troepe in die meer afgeleë forte. ${ }^{68}$ )

In die tweede brief hierbo kom veral die vraag na vore wat bedoel word met die bjt jhwh: is dit die tempel te Arad, of dié te Jerusalem? Hierdie vraag word nogal 'n bietjie interessanter as in gedagte gehou word die merkwaardige vonds wat gemaak is in verband met die tempel wat te Arad opgegrawe is. Daar is naamlik gevind dat die grondplan en afmetings van hierdie tempel baie noukeurig ooreenstem met die O.T.-gegewens in verband met die bou van die tabernakel en die tempel van Salomo. ${ }^{69}$ ) Omdat hierdie brief egter gedateer word in die tyd ná die hervorming van Josia waarby die sentralisasie van die kultus te Jerusalem weer beklemtoon is, is dit moeilik aanvaarbaar dat verwys sou word na 'n tempel van Here in Arad, en daarom word gemeen dat die tempel van Jerusalem bedoel word. Eljašib moes dan op een of ander manier verbonde gewees het aan, of intieme kennis gedra het van die tempel in Jerusalem. In elk geval blyk dit verder dat hy verantwoordelik was vir die opberging van wyn, meel en olie te Arad, om dit te voorsien aan reisigers in opdrag van die koning.

Die een naam wat verder in die tweede brief voorkom, die Qerosiet, is die naam van een van die families wat behoort het tot die tempelslawe (Esra $2: 43$ ), en dit is dus moontlik dat Arad verbonde was aan die diens van die administrasie van priesters en Leviete. Dan het Arad selfs ná die hervorming van Josia 'n groot rol gespeel as administratiewe sentrum in priesterlike diens..$^{70}$ )

\section{Moabitiese inskripsies}

\section{a) Mesa-steen}

Die bekende Mesa-steen, oorwinningstele van koning Mesa van Moab, is nie deur opgrawingsarbeid gevind nie, maar is vir die eerste keer in 1868 opgemerk in die ruïnes van die Moabitiese stad Dibon. Die steen het in die hande van die 
plaaslike Arabiere gekon, en toe die Fransman ClermontGanneau te veel belangstelling in die steen begin toon, het die Arabiere gedink dat daar 'n skat binne in die steen moes wees. Deur die steen te verhit en skielik met koue water af te koel, het hulle dit in stukke laat spring, sonder om enige skat te vind, natuurlik, maar daardeur het hulle tegelyk hicrdie waardevolle getuienis uit die vroeë Moabitiese geskiedenis verniel. Dieselfde Fransman e.a. het egter tog daarin geslaag om die meeste stukke van die steen in die hande te kry en aan die Louvre in Parys te laat toekom. Daar is die verskillende fragmente moeisaam weer inmekaar gepas en die steen verder met gips herstel. Die grootste deel van die inskripsie kon toe, ten spyte van die ramp, tog deur die wetenskap gelees en bestudeer word..$^{71}$ )

Die taal waarin hierdie inskripsie geskryf is, algemeen bekend as Moabities, verskil maar baie weinig van die $\mathrm{He}$ breeus wat betref grammatika, sintaksis en woordeskat. Daar is slegs 'n paar woorde wat hier gebruik word wat nie ook in die O.T. gebruik word nie, hoewel soms met 'n klein betekenis-verskil.72)

Die vertaling van hierdie inskripsie lui soos volg:73)

1. Ek is Mesa, die seun van $k m s[j t]^{74}$ ), die koning van Moab, die Di-

2. boniet. My vader was dertig jaar koning oor Moab en ek het koning

3. geword ná my vader. En ek het hierdie heiligdom gemaak vir Kamos in qrhh...

4. ... omdat hy my verlos het van al die konings ${ }^{75}$ ) en omdat hy my met welgevalle laat neersien het op my vyande. Wat betref Omr-

5. i, die koning van Israel, hy het Moab baie dae verdruk, want Kamos was toornig op sy la-

6. nd. En sy seun het hom opgevolg en ook hy het gesê: Ek sal Moab verdruk. In my dae het hy (so?) gesê

7. maar ek het met welgevalle neergesien op hom en op sy huis. En wat Israel betref, hy het vir altyd heeltemal omgekom. En Omri het in besit geneem die [hele? lan-]

8. d $m h d b^{\prime}$. En hy het daarin gewoon sy dae en die helfte van die dae van sy seun(s), veertig jaar, maar

9. in my dae het Kamos daarin gewoon. ${ }^{76}$ ) En ek het $b^{c} l m^{c} n$ gebou en ek het daarin die vywer gemaak en ek het geb[ou] 
10. qritn. En die mense van Gad het van oudsher gewoon in die land ctrt en vir homself het gebou die koning van I-

11. srael ctrt. En ek het teen die stad geveg en dit ingeneem. En ek het om die lewe gebring die hele volk

12. van die stad tot versadiging ${ }^{77}$ ) van Kamos en Moab. En ek het van daar af teruggebring die altaar van sy $d w d^{78}$ ), en ek het hom ge[sl-]

13. eep voor Kamos in qrjt. En ek het die mense van $\check{r} r n$ daar laat woon, en die men[se]

14. van mhrt. En Kamos het aan my gesê: Gaan, verower Nebo op Israel. En ek het ge-

15. gaan in die nag en daarteen geveg van die breek van die dag tot die middag en ek het dit inge-

16. neem en (hulle) almal om die lewe gebring; sewe duisend $m$ [ans en seuns] en vrouens en [dogter]s

17. en by-slavinne. Want vir Astar-Kamos het ek dit met die ban getref. En van daar af het ek geneem [die heilige voorwer-]

18. pe van Jahwe en ek het hulle gesleep voor Kamos. En die koning van Israel het gebou

19. jhs en hy het daarin gewoon terwyl hy teen my geveg het. En Kamos het hom uitgedryf voor [my. En]

20. ek het geneem uit Moab twee honderd man, almal aanvoerders. ${ }^{79}$ ) En ek het hulle na $j h s$ gebring en dit ingeneem

21. om dit by Dibon te voeg. En ek het grhh gebou, die muur van die park en die muur

22. van die vesting. En ek het gebou sy poorte, en ek het gebou sy torings. En e-

23. $\mathbf{k}$ het gebou die huis van die koning, en ek het gemaak die ommuring van die vywer ${ }^{80}$ ) vir die fontein binne

24. die stad. En 'n waterbak was daar nie in die stad, in qrhh nie, en ek het vir die hele volk gesê: Maak vir

25. julle elkeen 'n waterbak in sy huis. En ek het die balke gekap vir grhh met gevangene-

26. s van Israel. Ek het gebou ${ }^{c} r^{c} r$ (Aroër) en ek het die hoofweg by die 'rnn (Arnon) gemaak.

27. Ek het gebou $b t b m t$, want dit was verwoes. Ek het $b s ̣ r$ gebou, want dit was puinhope.

28. met vyftig [man]ne ${ }^{81}$ ) van Dibon, want die hele Dibon was gehoorsaam (aan my). ${ }^{82}$ ) En ek het as koning gerege-

29. er $[\ldots \ldots]$ honderd in die stede ${ }^{83}$ ) wat ek by die land gevoeg het. En ek het geb- 
30. ou [mhd] $b^{\prime}$ en bt dbltn en bt $b^{c} l m^{c} n$, en ek het daar geplaas die...

31. ... kleinvee van die land. En wat hwrnn betref... het daarin gewoon ...

32. ... Kamos het aan my gesê: Trek af, veg teen ḩwrnn. En ek het afgetrek.

33. ... Kamos in my dae

34. ......

Hierdie inskripsie beskryf, soos uit die inhoud blyk, die vrymaking van die Moabiete, m.n. na die gebeurtenisse wat beskryf word in 2 Kon. $3: 4$ vgl., veral vss. 27 e.v. Van die tyd van Salomo af het die Moabiete probeer om hulle vryheid te herwin. Watter vryheid hulle ook al geniet het, is hulle toe weer ontneem deur die Israelitiese koning Omri. $\mathrm{Na}$ die dood van koning Agab het Mesa, koning van Moab, sy mag herstel in die ou Moabitiese gebied. Koning Joram van Israel en koning Josafat van Juda het met mekaar 'n verbond gesluit en teen Moab uitgetrek. Na aanvanklike sukses moes hulle later tog die aftog blaas. Koning Mesa van Moab was verder ook nie tevrede met bloot die bevryding van die besette stede nie, maar hy het ook nuwe stede gebou en versterk, soos in die inskripsie genoem.

\section{b) El-Kerak-inskripsie}

Naas 'n tweede Moabitiese inskripsie wat by die opgrawings by Dibon gevind is in 1951, en waarop miskien gelees kan word:

tempel van $\mathrm{Ka}[\mathrm{mos}],{ }^{84}$ )

is daar nog 'n basalt-stele waarop nog 'n Moabitiese inskripsie voorkom. Hierdie stele is deur die Museum van Amman aangekoop in 1958, en is volgens opgaaf gevind by el-Kerak (die Bybelse Kir, Kir-Hareset en Kir Heres), toe dáár 'n ou muur afgebreek is. ${ }^{85}$ )

Die inskripsie op hierdie stele lees soos volg:

1. ...]mŝjjt mlk $m^{\prime} b$ hd $[\ldots$

2. ...]t kms lmbic $k j ' h[\ldots$

3. ...]nh whn ${ }^{c} s t j$ 't $[\ldots$

Vertaling:

1. [Ek, Mesa, seun van $k] m s ̌ j t^{86}$ ) koning van Moab, die Di[boniet 
2. ...] van (?) Kamos tot 'n altaar, ${ }^{87}$ ) omdat [...

3. ...] sy ... En kyk, ek het gemaak ..[...

Paleografies moet ook hierdie inskripsie gedateer word in die negende eeu v.C. Die inhoud, veral reël 3 maak die indruk dat dit ' $n$ wy-inskripsie kan wees. 'n Baie belangrike ontdekking uit hierdie inskripsie is egter, as die restitusie van reël 1 ten minste korrek is, wat baie waarskynlik is, die lesing van die naam van die vader van Mesa. Op die Mesa-steen kan die naam gelees word $k m \tilde{s}$... Uit hierdie inskripsie blyk dan dat die naam kan uitgebrei word tot $k m s ̌ j t .{ }^{88}$ ) Die teofore element in die naam is sonder twyfel die naam van die Moabitiese god, Kamos. Wat die tweede deel van die naam beteken, is nie so seker nie, maar dit kan 'n afleiding wees van die werkwoord $n t n$, "gee". ${ }^{89}$ )

In vergelyking met die groot aantal inskripsies van die ou volke rondom Palestina, veral Egipte en Assirië-Babilonië waar soms volledige biblioteke opgegrawe is, is die getal oud-Hebreeuse inskripsies nog maar gering. Dit wat wel gevind is, bied dankbare stof vir navorsing op verskillende gebiede. Dia vraag kom egter na vore of daar nie in hierdie feit juis 'n Goddelike bedoeling opgesluit lê nie, nl. dat die geskiedenis van die uitverkore volk in die Bybel gegee is, en dat daar nie ter wille dáárvan na inskripsie-materiaal gesoek en teruggegryp hoef te word nie. ${ }^{90}$ )

P.U. vir C.H.O.

E. J. Smit.

\section{VOETNOTE}

1) H. J. Franken, Clay tablets from Deir cAlla, VT 14 1964, pp. 377-9. Cf. ook H. J. Franken, The stratigraphic context of the clay tablets found at Deir cAlla, PEQ 96, 1964, pp. 73-78.

2) Cf. bv. S. Talmon, The Gezer calendar and the seasonal cycle of ancient Canaan, JAOS 83, 1963, p. 177; en H. Donner en W. Röllig, Kanaanäische und aramäische Inschriften (verderaan genoem Donner, Inschriften) II, Wiesbaden 1964, p. 181; H. Michaud, Op steen en klein (verderaan genoem Michaud, Steen), Nijkerk 1959, p. 23.

3) J. H. Segal, "Yrh" in the Gezer „calendar”, JSS VII 1962, p. 214 meen egter dat slegs een sinnetjie as gevolg van 'n skryffout uitgevee en oorgeskryf is. Die letters onder aan die linkerhoek vorm dan deel van die naam van die skrywer, cf. ook M. Lidzbarski, Ephemeris für semitische Epigraphik III, Giessen 1915, p. 38.

4) W. F. Albright, The Gezer calendar, BASOR 92, 1943, p. 24 beskou 
jrhw as ' $\mathrm{n}$ dualis-vorm met pron. suffiks $3 \mathrm{e}$ pers. ml. ekv. Hy vertaal dan „His two months ens..."; cf. ook id. in ANET, p. 320; J. Mauchline, The Gezer calendar, in Documents from Old Testament times, ed. D. W. Thomas, Londen ens. 1958 (verder DOTT), pp. 201-2; Donner, Inschriften II, p. 181. Segal, op. cit., pp. 212-221 meen egter dat nie jrhw gelees moet word nie, maar dat die teken wat vir $w$ aangesien word, eintlik 'n teken vir die getal 2 is; so dan in reëls $1(2 \mathrm{x}), 2$ en 6.

5) S. Talmon, op. cit., pp. 177-187 meen egter dat hier nie van vlas nie, maar van groen plante as groenvoer sprake is.

6) Michaud, Steen, p. 24. Cf. ook Mauchline in DOTT, p. 201

7) Segal, op. cit., p. 221.

8) G. A. Reisner e.a., Harvard excavations at Samaria 1908-1910, vol. I. Text, Cambridge 1962, p. 227.

9) Cf. A. Parrot, Samaria, hoofstad van het koninkrijk Israël, Nijkerk 1957, p. 66 en n. 67.

10) Bv. W. F. Albright in ANET, p. 321

11) Donner, Inschriften II, p. 183.

12) Reisner e.a., op. cit., p. 233.

13) Reisner e.a., op. cit., p. 230. Cf. egter die diskussie hieroor in IEJ 9, 1959, pp. 184-7, IEJ 12, 1962, pp. 62-3, 64-6, 67-9.

14) Vir lokalisering van die plekke cf. F. M. Cross, jr., A new reading of a place name in the Samaria ostraca, BASOR 163, 1961, p. 12-14.

15) Cf. ook J. N. Schofield, Inscribed potsherds from Samaria, DOTT, p. 205.

16) 2 Kon. $20: 20 ; 2$ Kron. $32: 30$, en cf. J. H. Kroeze, Koning Hiskia, Potchefstroom 1962, pp. 64-5.

17) Blokhake dui moontlike herstel van 'n beskadigde teks aan; puntjies dui op 'n onleesbare teks; wat in gewone hakies staan wörd gegee ter aanvulling van die vertaling.

18) Lesing onseker. Cf. Th. C. Vriezen en J. H. Hospers, Palestine inscriptions (verder: Vriezen, Inscriptions), Leiden 1951, p. 28 n. 5.

19) Kroeze, Hiskia, p. 65.

20) Cf. G. E. Wright, Biblical archaeology (rev. ed.), PhiladelphiaLonden 1966, p. 175.

21) Cf. Wright, Biblical archaeology p. 175. H. J. Katzenstein, The royal steward, IEJ 10, 1960, p. 153 wil dit egter eerder verbind aan Hilkia, die vader van Eljakim, cf. Jes. 22 : 20 e.v.

22) J. Naveh, Old Hebrew inscriptions in a burial cave, IEJ 13, 1963, pp. 75 e.v.

23) Naveh, op. cit., p. 81 e.v. M. Weippert, Archäologischer Jahresbericht, ZDPV 80, 1965, pp. 162 e.v. wys daarom ook daarop dat die lesings van Naveh baie onseker is.

24) Th. C. Vriezen, Jahwe en zijn stad, Amsterdam 1962.

25) Vriezen, op. cit., pp. 3-4.

26) Naveh, op. cit., p. 85 n. 23.

27) Naveh, op. cit., pp. 89 e.v.

28) Cf. J. L. Starkey, The discovery, in H. Torczyner e.a., Lachish I (Tell ed-Duweir), The Lachish letters. Londen ens, 1938, pp. 11-13 D. Diringer, Early Hebrew inscriptions, in O. Tufnel e.a., Lachish III (Tell ed-Duweir). The iron age, Londen ens., 1953, p. 339 
29) Lachish I. Cf. n. 28.

30) Diringer in Lachish III. Cf. n. 28.

31) Cf. Wright, Biblical archaeology, pp. 178-179; S. du Toit, Ou Testament en opgrawinge, Potchefstroom 1966, p. 427.

32) So Torczyner, Lachish I, pp. 62 e.v.

33) So J. W. Jack. The Lachish letters, ExpT 49, 1937-38, pp. 168-9; en id., The Lachish letters, their date and import, PEQ 70, 1938, pp. 165 e.v.

34) Nrs. 1 en 19 word weggelaat omdat hulle slegs 'n aantal eiename bevat.

35) Laaste gedeelte onseker.

36) Die vertaling word bemoeilik deur 'n beskadigde teks. Die vertaling moet hier kies tussen twee moontlikhede; of dat hy beskuldig word dat hy wederregtelik briewe gelees het wat nie vir hom bestem was nie, of dat hy nie die briewe wat tot hom gekom het, goed kon lees nie; hy hou vol dat hy wel elke brief gelees het, of dat hy 'n betrokke brief(-we) nooit gesien het nie.

37) Miskien was opdragte ter kennisname op die deur aangebring? Die woord dlt is egter vatbaar vir verskillende interpretasies; cf. bv. D. W. Thomas, Letters from Lachish, DOTT, p. 216.

38) 'n Pleknaam?

39) Lesing soos by Donner, Inschriften $I$, p. 35

39a) Hierdie vertaling berus op 'n lesing van $H$. Michaud, Les ostraca de Lakis conservés à Londres, Syria 34, 1957, p. 40.

40) Lesing volgens Donner, Inschriften I, p. 36.

41) Lesing onseker.

42) Hierdie en die volgende vyf reëls is bykans nie lees- en verstaanbaar nie.

43) Cf. R. de Vaux, Les ostraka de Lachis, RB 48, 1939, p. 205; D. W. Thomas, Letters from Lachish, DOTT, pp. 216-217; K. Elliger, Die Ostraka von Lachis, Palästinajahrbuch 34, 1938, 54.

44) Vgl. hierby ook Jer. $6: 1:$,...blaas die basuin in Tekoa, en hef 'n vuurteken op bo Bet-hakkerem".

45) Vir die ander inskripsies vgl. J. Naveh, More Hebrew inscriptions from Meșad Hashavyahu, IEJ 12, 1962, pp. 27-32.

46) Alhoewel die naam Hašabjahu ook later gelees is as $h w s c i h w$, cf. F. M. Cross, jr., Epigraphic notes on Hebrew documents of the eighth-sixth centuries B.C.: II. The Murabbacât papyrus and the letter found near Yabneh-Yam, BASOR 165, 1962, p. 43.

47) Cross, op. cit., p. 43.

48) Cf. J. Naveh, IEJ 10, pp. 131 e.v.; J. D. Amusin en M. L. Heltzer, The inscription from Mesad Hashavyahu, IEJ 14, 1964, 149; S. Talmon, The new Hebrew letter from the seventh century B.C. in his historical perspective, BASOR 176, 1964, p. 29; S. Yeivin, The judicial petition from Mezad Hashavyahu, BiOr XIX, 1962, p. 3.

49) Lesing volgens Amusin en Heltzer, op. cit., p. 151; Cross, op. cit., p. 43. J. Naveh, Some notes on the reading of the Mesad Hashavyahu letter, IEJ 14, 1964, p. 158 het ook hierdie lesing aanvaar.

50) So volgens Cross, op. cit., p. 43.

51) So volgens Amusin en Heltzer, op. cit., p. 151.

52) Pi. van klh, soos by Amusin en Heltzer, op. cit., p. 151; E. Vogt, 
Ostracon Hebraicum saec. 7 A.C., Biblica 42, 1961, p. 135. Talmon, op. cit., p. 31 en Cross, op. cit., p. 44 neem dit egter van die werkwoord $k w l$, om te meet, weeg.

53) kjmm: "soos gewoonlik, normaalweg", volgens Cross, op. cit., pp. 31-32, en Heltzer in Amusin en Heltzer, op. cit., p. 151.

54) Die sin kan ook begin met "Voor die Sabbat, toe..." soos by Cross, op. cit., p. 44. Yeivin, op. cit., p. 5 vertaal hier op grond van sy lesing: .So thy servant reaped and finished (his assigned lot), while the storer was slumbering, before I rested". Die volgende word dan ook ooreenkomstig vertaal.

55) In die betekenis van mede-arbeiders, cf. bv. Talmon, op. cit., p. 34.

56) Yeivin, op. cit., p. 6 vertaal r. 11 v.: ,...my brethren will testify on my behalf, whether I have been short of my assigned lot any [thing; and (even) if not, please return my garment..."

57) Talmon, op. cit., p. 35 verkies om hier anders te lees en vertaal: „I testify that I had discharged myself of what you had imposed on me..., and he (Hoshaiah, nevertheless) did take my garment".

58) Met $m l^{\prime}$ in die betekenis van "roep, roep met 'n harde stem", cf. Koehler-Baumgartner, Lexicon s.v.; Amusin en Heltzer, op. cit., p. 154.

59) Yeivin, op. cit., pp. 5, 6: ,do not stun me".

60) Cf. Cross, op. cit., p. 46. I. Mendelsohn, On corvée labor in ancient Canaan and Israel, BASOR 167, 1962, p. 34 sien ons klaer as 'n vrye boer wat korvee-diens moes verrig op 'n koninklike landgoed; cf. ook K. R. Veenhof, Nieuwe Palestijnse inscripties, Phoenix XI, 1965, p. 251; Yeivin, op. cit., pp. 8-10.

61) Cf. Deut. 24 : 12-13; Eks. 22 : 25-26; cf. ook Amusin en Heltzer, op. cit., p. 152, 154-155; Vogt, op. cit., p. 136.

62) Cf. IEJ 14, 1964, p. 282.

63) Cf. Y. Aharoni, Hebrew ostraca from Tel Arad, IEJ 16, 1966, p. 1.

64) Aharoni, op. cit., p. 1.

64a) Eers nadat hierdie artikel voltooi was, het die artikel van $Y$. Aharoni, The use of hieratic numerals in Hebrew ostraca and the shekel weights, BASOR 184, 1966, pp. 13 e.v. onder ons aandag gekom, waarin op pp. 14 en 15 'n weergawe van die oorspronklike, ' $n$ transskripsie en 'n vertaling gegee word van hierdie brief. Die transskripsie is soos volg:

Voorkant:

1. 'I nhm wet b

2. ' bjth 'ljsb

3. bn 'sjhw wlqh

4. $t m[$ 'th ?] $l$ smn $w$

5. $\operatorname{sih} l[j$ ? ] $m h r h w$

6. $h t m$ 'th bh

7. $t m k$

Agterkant:

8. $b 24$ thds ntn nhm 5

9. $m n$ bjd $h k t j$

Die vertaling lui in ooreenstemming met die van Aharoni:

Voorkant:

1. Aan Nahum, en nou: kom 
2. na die huis van Eljašib

3. die seun van Ešjahu en neem

4. van hom (?) 1 (kruik) olie en

5. stuur (dit) na [my ?] gou, en

6. verseël dit met jou

7. seël.

Agterkant:

8. Op die 24 ste van die maand het Nahum afgegee 0 -

9. lie in die hand van die Kittiër

65) Cf. Koehler-Baumgartner, Lexicon, s.v. ktjim.

66) Cf. D. J. Quinn, Alcaeus 48 (B 16) and the fall of Ascalon (604 B.C.), BASOR 164, 1961, pp. 19-20.

67) Cf. J. Naveh, The excavation at Mesad Hashavyahu. Preliminary report, IEJ 12, 1962, pp. 97-99; en Aharoni, op. cit., p. 4.

68) Aharoni, op. cit., p. 4.

69) Cf. IEJ 14,1964 , p. 282

70) Cf. Aharoni, op. cit., p. 7

71) Cf. Michaud, Steen, pp. 36 e.v.; A. Parrot, De schatten van het Louvre en de Bijbel, Nijkerk 1958, pp. 96-97.

72) Cf. E. Ullendorf, The Moabite stone, DOTT, p. 196.

73) In hoofsaak word die Afrikaanse vertaling gevolg van A. H. van $\mathrm{Zyl}$ Die Moabiete, (diss.) Pretoria 1955, pp. 402 e.v., behalwe wat betref die eiename, wat of in die bekende vorme, of in transskripsie weergegee word.

74) Die name van die vader van Mesa is hier beskadig. Dit moet saamgestel wees met die teofore element Kamos (god van die Moabiete) $\mathrm{Na}$ aanleiding van die el-Kerak-inskripsie (sien onder) moet die naam waarskynlik lees: $k m s ̌ j t$, cf. D. N. Freedman, A second Mesha inscription, BASOR 175, 1964, p. 50; Donner, Inschriften II, p. 170

75) So Van Zyl, Moabiete, p. 403; W. F. Albright in ANET, p. 320; Ullendorf in DOTT, p. 196. Baie geleerdes lees egter anders; cf. Donner, Inschriften I, p. 33 en II, p. 172

76) $\mathrm{Na}$ algemene aanvaarde teksherstel.

77) Die betekenis van rit is egter onseker.

78) So in navolging van Donner, Inschriften II, p. 169 en p. 175. Die betekenis van beide ' $r$ ' $l$ en $d w d$ is egter onseker. Van Zyl, Moabiete, p. 404 vertaal: „sy opperbevelhebber"; Albright in ANET, p. 320 "Arel its chieftain"; Ullendorf in DOTT, p. 197: „the altar-hearth of David".

79) So volgens W. F. Albright in ANET, p. 320; Donner, Inschriften II p. 169; Ullendorf in DOTT, p. 197.

80) So Van Zyl, Moabiete. Cf. ook Donner, Inschriften II 169; en F. M Cross, jr. en D. N. Freedman, Early Hebrew orthography, New Haven, 1952, pp. 41-42.

81) So volgens Van Zyl, Moabiete, p. 406; Albright, ANET, p. 321; Ullendorf, DOTT, p. 197, Donner, Inschriften I, p. 33 en II, p. 169.

82) Cf. Donner, Inschriften II, p. 178.

83) So volgens Donner, Inschriften II, p. 169. Daar is duidelik te lees m't bqrn, cf. id. I, p. 33; Vriezen, Inscriptions, p. 18, ens.

84) R. E. Murphy, A fragment of an early Moabite inscription from Dibon, BASOR 125, 1952, pp. 20-23; Michaud, Steen, p. 50. 
85) W. L. Reed en F. V. Winnett, A fragment of an early Moabite inscription from Kerak, BASOR 172, 1963, pp. 1 e.v.

86) Restitusie van ontbrekende gedeeltes volgens Freedman, BASOR 175 , 1964, p. 50.

87) $m b c_{r}$ word dan afgelei van die stam $b^{c} r \mathrm{Hi}$. en $\mathrm{Pi}$.: ,om aan die brand te steek", cf. Reed en Winnet, op. cit., pp. 8-9.

88) Cf. bo by Mesa-steen reël 1 .

89) Vgl. die beredenering by Donner, Inschriften II, p. 170; M. Weippert, Archäologischer Jahresbericht, ZDPV 80, 1965, pp. 169-170; Freedman, BASOR 175, 1964, p. 51 wys op die moontlike konneksie met die Edomitiese stamhoof $j t t$ (Jetet), Gen. $36: 40,1$ Kron. $1: 51$.

90) Cf. J. van Raalte, De schrijfkunst in de Bijbellande, Baarn s.j., p. 111. 